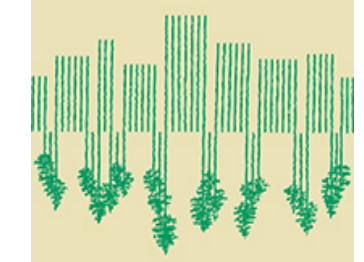

\title{
Impact of a Media Campaign on Consumers' Purchasing Intentions of Legal Timber in Cameroon
}

\section{Bienvenue Belinga, Colas Chervier \& Guillaume Lescuyer}

To cite this article: Bienvenue Belinga, Colas Chervier \& Guillaume Lescuyer (2021) Impact of a Media Campaign on Consumers' Purchasing Intentions of Legal Timber in Cameroon, Society \& Natural Resources, 34:5, 603-620, DOI: 10.1080/08941920.2020.1855686

To link to this article: https://doi.org/10.1080/08941920.2020.1855686

\section{(c) 2020 The Author(s). Published with} license by Taylor \& Francis Group, LLC

\section{曲 Published online: 13 Dec 2020.}

Submit your article to this journal $₫$

Џ Article views: 531

Q View related articles $₫$

View Crossmark data $\asymp$ 


\title{
Impact of a Media Campaign on Consumers' Purchasing Intentions of Legal Timber in Cameroon
}

\author{
Bienvenue Belinga $^{a}$, Colas Chervier ${ }^{b}$, and Guillaume Lescuyer ${ }^{b, c}$ \\ ${ }^{a}$ Department of Economics and Management, University of Yaoundé II, Yaoundé, Cameroon; ${ }^{\mathrm{b} C e n t r e ~ d e}$ \\ Coopération Internationale en Recherche Agronomique pour le Développement (CIRAD), UR Forests \& \\ Societies, University of Montpellier, Montpellier, France; ' $C e n t e r$ for International Forestry Research \\ (CIFOR), Bogor, Indonesia
}

\begin{abstract}
Illegal logging is a key driver of deforestation in tropical countries and benefits a large number of stakeholders, including urban domestic buyers. Changing the latter's purchasing behavior could produce significant shifts in the illegal trade market. Based on survey data $(n=463)$, this paper assesses the impact of a media campaign on consumers' purchase intentions for legal timber and wooden furniture in Yaoundé and analyses the underlying psychological mechanisms. Combining covariate matching and mediation analysis, we found a significant positive effect of the media campaign on the declared intention to purchase legally-sourced timber and the mediation effect of two out of three precursors of the theory of planned behaviors, namely attitude and subjective norms. This study provides critical inputs to frame future media campaign messages and, by demonstrating some consumers' interest in legal timber, to strengthen the domestic legitimacy of policies such as the Forest Law Enforcement, Governance and Trade.
\end{abstract}

\section{ARTICLE HISTORY}

Received 27 May 2020

Accepted 11 November 2020

\section{KEYWORDS}

Congo basin; consumption; covariate matching; FLEGT; illegal; mediation analysis; theory of planned behavior

\section{Introduction}

The illegal exploitation of forest resources is considered a significant cause of deforestation and forest degradation in tropical countries (Brown et al. 2008; Kleinschmit et al. 2016). Over the past 20 years, a great deal of attention has been paid to large-scale illegal logging activities and their connection with the international markets. The Forest Law Enforcement, Governance and Trade (FLEGT) Action Plan and sustainability certification schemes have emerged as a response to this issue (Gan et al. 2013; Lambin et al. 2014; D'Hollander and Tregurtha 2016). The FLEGT Action Plan uses a simple and consensual definition of illegal timber when harvesting, transporting, processing, buying or selling is in violation of national laws of the producing countries. The first objective of the FLEGT Action Plan is to secure imports of legal timber into the European Union through bilateral agreements with producer countries. In addition to ensuring the legality of their timber exports to the European Union, several producer 
countries, including Cameroon, Congo and Ghana, have also committed to applying this regulation to timber transactions on their domestic markets. However, these domestic markets have been overwhelmingly supplied with illegally sourced timber, mainly because of the complexity and cost for chainsaw millers to acquire a logging license (Wit et al. 2010). Promoting the legality of timber in domestic markets by focusing solely on producers is difficult due to the high cost of producing legal small-scale sawn wood and the reluctance of industrial companies to move into what they consider as a low-paying sector, at least in Central Africa (Lescuyer et al. 2017).

A complementary approach to a supply-side support strategy is to increase domestic demands for legal timber in order to develop this market niche and ensure a profitable outlet for producers. By demanding legal timber for public procurement, the State could contribute to the emergence of this specific market, but public procurement represents only a small percentage of the volumes traded on the domestic timber market (Lescuyer et al. 2017). Private buyers account for the bulk of national consumption of timber. Mitigating private buyers demand for illegal wood products represents today a promising but under-studied lever to increase the share of legal wood in the national market.

Mitigation of consumer demand for illegal forest-based products has traditionally been addressed through regulation and law enforcement but demand-reduction campaigns have gained traction in the recent years (Veríssimo and Wan 2019). A review of the literature on demand-reduction campaigns of illegally sourced forest products reveals at least four gaps of knowledge (Salazar, Mills, and Veríssimo 2019; Wallen and Daut 2018; Veríssimo and Wan 2019; Greenfield and Veríssimo 2019; Thomas-Walters et al. 2020). Firstly, most studies consider campaigns that target the consumption of illegal wildlife products, not timber. In their international synthesis on illegal logging and related timber trade, Kleinschmit et al. (2016) barely address options for reducing purchases of illegal timber by individual consumers. Secondly, the vast majority of these campaigns are implemented in distant consumer markets, such as China and Vietnam in the case of rhino horns and elephant ivory trade, or in Europe and USA through the promotion of FSC/ PEFC-certified timber. Knowledge on the relevance of demand-reduction campaigns in producer markets remains very limited. Thirdly, when such campaigns are experimented in producer countries, most studies points to the lack of robust evidence for the impact on consumer behaviors (Coad et al. 2017). Fourthly, the underlying behavioral assumption of these campaigns is often overly simplistic, which casts doubts on the capacity of these campaigns to induce behavioral change (Wallen and Daut 2018). For example, many educational campaigns assume that the simple lack of information prevent individuals from engaging in legal purchase behaviors. However, this assumption is valid in the narrow set of situations where consumers already have strong preexisting preferences for the desired behavior (Wallen and Daut 2018). Understanding the psychological mechanisms that underlie consumers' decision in a given context is thus of primarily importance to develop policy tools that are able to change consumers' preferences.

In this context, our contribution to the literature and the objectives of the study are twofold. First, we evaluate the impact of a multi-media campaign on the legal timber purchase intentions of Cameroonian consumers. Measuring the impact of such an intervention is not straightforward (Greenstone and Gayer 2009; Imbens and Wooldridge 2009). In particular, rigorous research design should disentangle the effect of the 
campaign from other factors likely to influence purchasing intentions. For example, a control-intervention comparison should take into account the fact that individuals who received the intervention often have specific characteristics that also influence their response to the intervention (this is known as selection bias). Scholars have increasingly used counterfactual methods such as quasi-experimental techniques in order to create comparison groups that represent what would have hypothetically happened in the absence of a program (Börner et al. 2017; Gilligan and Hoddinott 2007; Abebaw, Fentie, and Kassa 2010). In this study, we use covariate matching to estimate the impact of the campaign.

Second, we shed light on the underlying psychological mechanisms mediating the effect of the campaign on purchase intentions. Counterfactual methods generally fall short in providing information about the underlying pathways to impact (Baylis et al. 2016; Miteva, Pattanayak, and Ferraro 2012). For this reason, we use mediation analysis in order to achieve our second objective. Mediation analysis has been recently used to assess the determinants of consumption behaviors and the effects of policy interventions (Bamberg and Möser 2007; Johe and Bhullar 2016; Janmaimool and Khajohnmanee 2020; Prifti, Daidone, and Davis 2019; Ulambayar and Fernández-Giménez 2019). Mediation analysis requires the formulation of a model to be tested. In our case, we use the theory of planned behavior (TPB), proposed by Ajzen (1985). The three TPB constructs, namely attitude, subjective norms, and perceived behavioral control, have demonstrated their ability to predict consumption intentions and behaviors in various settings (Beedell and Rehman 2000; Chan and Lau 2002; Liobikiené, Mandravickaité, and Bernatoniené 2016; Gurney et al. 2016; Borges and Oude Lansink 2016; Johe and Bhullar 2016; Nath et al. 2017; Yadav and Pathak 2017).

\section{Materials and Methods}

\section{Description of the Media Campaign}

Between September and November 2018, a media campaign was undertaken in Yaoundé to raise awareness and promote legally sourced timber with a view to increasing domestic consumption of legally sawn wood. As far as we know, and on the basis of a 10-year collaboration with the Ministry of Forest and Fauna, this nation-wide campaign was the first to be organized in Cameroon to promote legally-source timber for domestic purchasers. The study targeted individual buyers. Three ex-situ and two in-situ media were combined for this campaign ${ }^{1}$ : (1) four radio programmes, including two one-hour sessions on Radio Environnement and two reports on Voice of America; (2) broadcasting of an information banner on the national television channel (CRTV) for two weeks; (3) a 1'30" animated film was broadcast on Facebook to 135,000 people; (4) 80 posters were put on display in timber markets, chambers of commerce and furniture showrooms; (5) 3,100 flyers were distributed to individual buyers in Yaoundé's markets.

The campaign messages were developed on the basis of an in-depth knowledge of the actors of the national timber market (Cerutti and Lescuyer 2011; Lescuyer, Cerutti, and Tsanga 2016) and a preliminary study of the sensitivity of these audiences to the legal origin of timber (Lescuyer et al. 2017). Several arguments in favor of legal timber were advertised by these media supports, linking legality to quality, forest conservation, 
Table 1. Measurement of items.

\begin{tabular}{|c|c|c|}
\hline TPB variables & Items & Likert Scale \\
\hline \multirow[t]{3}{*}{ Attitudes (ATT) } & $\begin{array}{l}\text { ATT26 Do you think buying legal timber is good for } \\
\text { preserving our forests? }\end{array}$ & $\begin{array}{l}1=\text { Very bad to } \\
7=\text { Very good }\end{array}$ \\
\hline & $\begin{array}{l}\text { ATT34 Do you think buying legal timber is useful in } \\
\text { the fight against climate change? }\end{array}$ & $\begin{array}{l}1=\text { Very useful to } \\
7=\text { Very necessary }\end{array}$ \\
\hline & $\begin{array}{l}\text { ATT50 Do you think buying legal timber today is } \\
\text { important for the well-being of future } \\
\text { generations? }\end{array}$ & $\begin{array}{c}1=\text { Not at all important to } \\
7=\text { Very important }\end{array}$ \\
\hline \multirow[t]{6}{*}{ Subjective norms (SN) } & $\begin{array}{l}\text { SN36 To what extent do you agree with the } \\
\text { following statement: "my colleagues think I } \\
\text { should purchase legal timber in future" }\end{array}$ & $\begin{array}{r}1=\text { Don't agree at all to } \\
7=\text { Completely agree }\end{array}$ \\
\hline & $\begin{array}{l}\text { SN38 To what extent is the following statement } \\
\text { possible: "my friends would approve of my } \\
\text { buying legal timber" }\end{array}$ & $\begin{array}{c}1=\text { Very impossible to } \\
7=\text { Very possible }\end{array}$ \\
\hline & $\begin{array}{l}\text { SN40 To what extent is the following statement } \\
\text { likely or possible: "Most people with my level of } \\
\text { education would purchase legal timber at their } \\
\text { next purchase" }\end{array}$ & $\begin{array}{c}1=\text { Very unlikely to } \\
7=\text { Very likely }\end{array}$ \\
\hline & $\begin{array}{l}\text { SN43 To what extent do you agree with the } \\
\text { statement that "my neighbours think I should buy } \\
\text { legal timber when I make future purchases" }\end{array}$ & $\begin{array}{r}1=\text { Don't agree at all to } \\
7=\text { Completely agree }\end{array}$ \\
\hline & $\begin{array}{l}\text { SN48 To what extent do you agree with the } \\
\text { following statement: "my family thinks I should } \\
\text { buy legal timber in future purchases" }\end{array}$ & $\begin{array}{r}1=\text { Don't agree at all to } \\
7=\text { Completely agree }\end{array}$ \\
\hline & $\begin{array}{l}\text { SN53 To what extent do you agree with the } \\
\text { following statement: "The authorities think I } \\
\text { should buy legal timber" }\end{array}$ & $\begin{array}{r}1=\text { Don't agree at all to } \\
7=\text { Completely agree }\end{array}$ \\
\hline \multirow[t]{4}{*}{$\begin{array}{l}\text { Perceived behavioral } \\
\text { control (PBC) }\end{array}$} & $\begin{array}{l}\text { PBC37 Can the time spent searching for or locating } \\
\text { legal timber be an obstacle to the purchase of } \\
\text { legal timber? }\end{array}$ & $\begin{array}{r}1=\text { Don't agree at all to } \\
7=\text { Completely agree }\end{array}$ \\
\hline & $\begin{array}{l}\text { PBC39 Can price be a setback for the purchase of } \\
\text { legal timber? }\end{array}$ & $\begin{array}{l}1=\text { Don't agree at all to } \\
7=\text { Completely agree }\end{array}$ \\
\hline & $\begin{array}{l}\text { PBC } 45 \text { Can your income be a setback for buying } \\
\text { legal timber? }\end{array}$ & $\begin{array}{l}1=\text { Don't agree at all to } \\
7=\text { Completely agree }\end{array}$ \\
\hline & $\begin{array}{l}\text { PBC47 Can the distance traveled in search of legal } \\
\text { timber be a setback for your willingness to } \\
\text { purchase legal timber? }\end{array}$ & $\begin{array}{r}1=\text { Don't agree at all to } \\
7=\text { Completely agree }\end{array}$ \\
\hline Purchase Intention & $\begin{array}{l}\text { Your intention to focus on timber of legal origin } \\
\text { when it is acquired in the future is ... }\end{array}$ & $\begin{array}{l}1=\text { Very weak to } \\
7=\text { Very strong }\end{array}$ \\
\hline
\end{tabular}

improvement of rural livelihoods, patriotism, and emotions. They also included information on how to recognize and where to find legal timber by (1) asking the seller, (2) calling one among the four local associations that support legal timber in Yaoundé, or (3) looking at the sawn wood quality (i.e. legal sawn wood is usually dry and straight, streak-free, and with sharp edges).

\section{Survey and Sampling Procedures}

We sampled respondents in 13 timber markets and 35 carpentry workshops and furniture showrooms in Yaoundé, that were demonstrated to be the most important in volume in Yaoundé (Cerutti and Lescuyer 2011; Lescuyer et al. 2017). The survey was not subject to prior approval from an ethical committee but was developed and supervised by a researcher with a certificate in "Social and Behavioral Responsible Conduct of Research". The respondents did not provide a formal Free, Prior and Informed Consent but the interview started with an overview of the background, the team, the type of question they would be asked and the approximate duration of the interview. It was 
also stated that information collected during this survey was strictly confidential, and, according to the Cameroonian Law No. 91/023 of December 16, 1991 on Censuses and Statistical Surveys, might under no circumstances be used for the purposes of economic control or repression. Lastly, it was mentioned that the respondent would not receive any retribution for their participation to the survey.

Data were collected using a paper questionnaire conducted in French. The questionnaire was previously tested on 30 clients and amended.

To increase the chances of evaluating people exposed to the legal timber awareness campaigns, we conducted surveys at sites where large numbers of flyers and posters had been distributed. In each site, enumerators spent two days visiting all the shops and interviewing all the customers who entered each of the shops. All the respondents had the choice to participate or not in the survey.

After data cleaning, the total sample consisted of 463 respondents.

\section{Construction of Variables}

The questionnaire was organized in two sections. The first section included questions on the respondent's socio-economic characteristics, including age, education, household size, the socio-professional category as well as the past purchase behavior of legal wood before the information campaign. The first section of the questionnaire also captured the treatment variable ("information"), i.e. whether or not the individual was actually exposed to the awareness campaign. It was measured using a dichotomous variable derived from the following question: "Did you see, read or hear about the legal timber campaign?"

The second section of the questionnaire brought together the TPB constructs adapted to our study context (Table 1). Attitude is defined as the positive or negative assessment of whether or not a given behavioral aspect has been implemented (Ajzen and Fishbein 1980). Attitude was measured in our study using a three-item Likert scale based on Borges and Oude Lansink (2016). Subjective norms correspond to the social pressure perceived by the individual to adopt the behavior of reference groups (friends, families, neighbors, colleagues, spouses, etc.). Following Chan and Lau (2002), the subjective norm was measured in our study using a six-item Likert scale that referred to different groups of stakeholders likely to exert social pressure. Perceived behavioral control (PBC) is defined as "the perceived ease or difficulty in performing behaviour" (Ajzen 1987). PBC was measured in our study using a 4-item Likert scale (Lalani et al. 2016). Our test questionnaire revealed that the main obstacle to purchasing legal timber was the limited availability of the product. We thus considered using access to legal timber as a proxy for PBC. Lastly, intention to purchase was measured using a single item.

In the final questionnaire, we organized the questions in such a way that related items did not follow each other to ensure that each answer was independent from the previous one. Attitude, Subjective Norm and PBC variables were obtained by calculating the mean of the Likert scales for all items related to each of the mediators. Only the items that were loaded on the same factor were retained. We tested the convergence and reliability of the Likert scales using major component factor analysis (MCFA) with 
a Kaiser-Meyer-Olkin test (KMO), the Cronbach alpha coefficient and the eigenvalue. Results of these tests are presented in Appendix 1.

\section{Data Analysis}

\section{Impact Analysis}

Our first objective is to assess the impact of the media campaign on purchase intentions. We hypothesize that the two different means of communication used for this multi-media campaign have different impacts. Therefore, we estimate not only the overall impact of the campaign but we also assess the impact of the two main communication channels separately.

Our impact estimate is the average treatment effect on the treated obtained by calculating the mean difference in purchase intention between treated (i.e. exposed to the media campaign) and matched control (i.e. not exposed to the media campaign) wood consumers (Ho et al. 2007; Imbens and Wooldridge 2009).

Covariate matching was used to control for observable sources of bias, i.e. preexisting differences between the treated and control group in observable characteristics that explain the exposition to the media campaign and the purchase intention in the absence of the media campaign. We use the socio-economic characteristics (age, education, household size and the socio-professional category) and the past purchasing behavior of respondents as covariates. These variables are suitable covariates because they were likely to influence pro-environmental behaviors (Mainieri et al. 1997; Lalani et al. 2016; Laroche, Bergeron, and Barbaro-Forleo 2001; Samdahl and Robertson 1989; Webster 1975) and were not likely to be influenced by the media campaign (e.g. it is unlikely that the size of the family would change as a result of being exposed to the media campaign).

We use $\mathrm{R}$ version 3.6.1 and the Matchit package (Ho et al. 2011) to calculate the Mahalanobis distance as a measure of observable similarity between respondents (Ho et al. 2007). In order to obtain our control group of consumers, we then apply one-toone nearest-neighbour matching with replacement. This procedure matches each treated individual to the nearest control individual using the Mahalanobis distance.

We assessed the performance of the matching procedure by carrying out a test consisting in comparing the standardized difference in means before and after matching each covariate (Imbens and Wooldridge 2009; Stuart 2010). Standardized difference in means is given by the difference in the ratio between treated and control of the mean divided by the standard deviation in both group. According to Rubin (2001), for the adjustment to be trustworthy, the absolute value of the standardized difference must be less than 0.25.

Matching assumes that there is no hidden bias. We estimated Rosenbaum's test to measure the level of influence of an unobservable covariate that could affect the estimated treatment effect (Arriagada et al. 2012). More specifically, we estimated test statistics for different levels of the odds ratio, $\Gamma$, where a higher odds ratio is associated with unobservable variables playing a larger role in the selection of individual and the probability of individuals to display intentions to buy legal wood (Shah and Baylis 2015). In the absence of hidden bias, $\Gamma$ is equal to one. The higher the level of $\Gamma$ to 


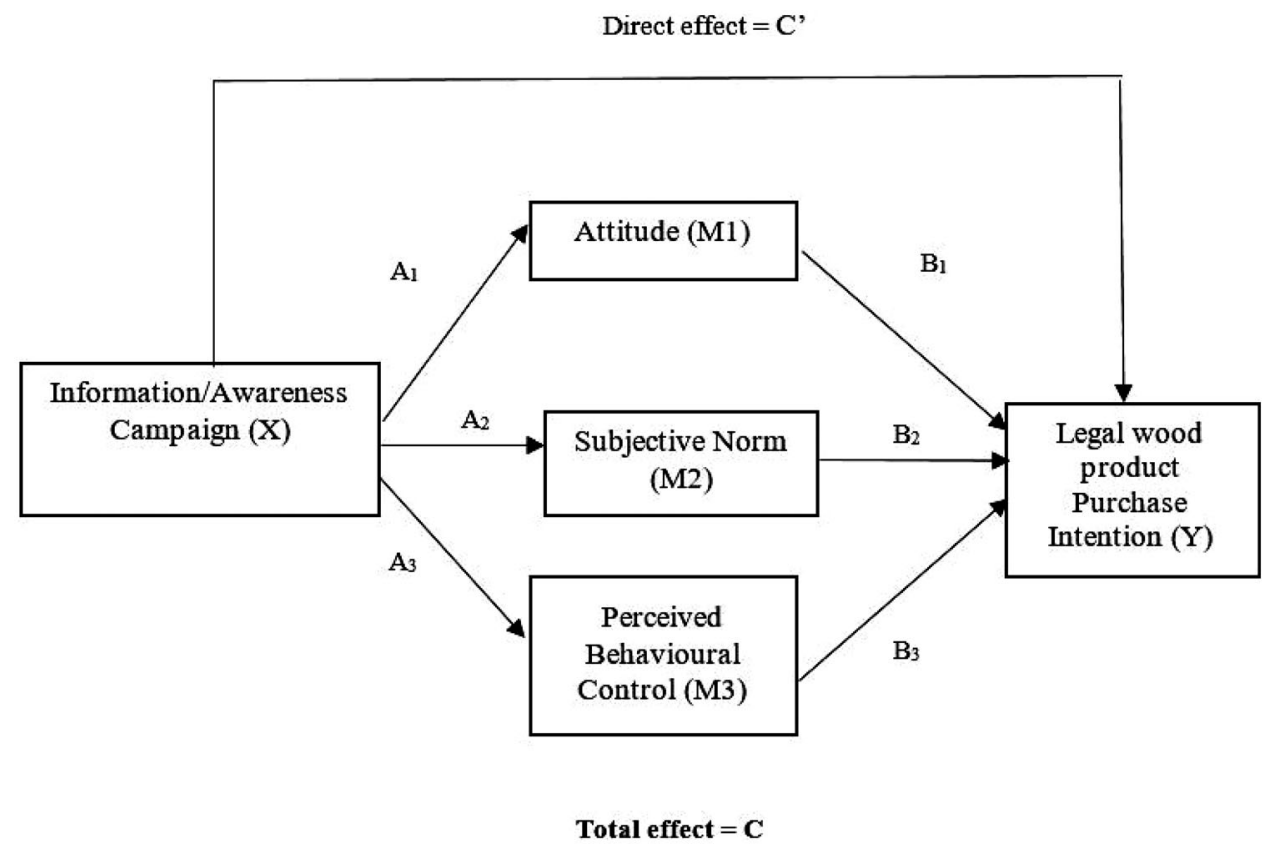

Figure 1. Theoretical model of the possible influence of information on legal wood products purchase via three mediators. Note: Arrows show the direction of the effect. $C$ and $C^{\prime}$ are, respectively, the total and direct effect of information $(X)$ on Purchase Intention (Y). $A 1, A 2$, and $A 3$ are the specific indirect effects of information $(X)$ on each of three mediators (M1, M2, and $M 3) . B 1, B 2$, and $B 3$ are the specific indirect effects of each mediator on Purchase Intention.

which the estimated effect of the media campaign on purchase intention remains significantly different from zero, the more confidence one can have in the conclusion that the estimate is a causal effect.

\section{Mediation Analysis}

Our second objective is to examine the mechanisms through which the awareness campaign influenced people's intentions to purchase legal timber. To this end, we performed a parallel mediation analysis using the macro PROCESS version 3.4 (Hayes 2018) in SPSS. The parallel mediation model measures simultaneously the total, direct and indirect effect of the campaign $(\mathrm{X})$ on the intention to purchase $(\mathrm{Y})$ while examining the specific indirect effects associated with each of the three intermediate outcomes (M1, M2, M3). Figure 1 presents the model in which the intermediate outcomes are the precursors of the TPB, namely attitude (M1), social norms (M2) and PBC (M3).

The total effect $\mathrm{C}$ is the sum of the direct effect $\mathrm{C}^{\prime}(\mathrm{X} \rightarrow \mathrm{Y})$ and the total indirect effect $(\mathrm{X} \rightarrow \mathrm{M} \rightarrow \mathrm{Y})$. In turn, the total indirect effect corresponds to the sum of the three specifics indirect effects $(\mathrm{X} \rightarrow \mathrm{M} 1 \rightarrow \mathrm{Y}+\mathrm{X} \rightarrow \mathrm{M} 2 \rightarrow \mathrm{Y}+\mathrm{X} \rightarrow \mathrm{M} 3 \rightarrow \mathrm{Y})$. Each estimated specific indirect effect is the product of the regression coefficients corresponding to each step of an indirect path, that is $A_{i} * B_{i}$. The mediation model also estimates the effect of each covariate (age, household size, past purchasing behavior, socio-professional category, and education) on M1, M2, M3 and Y. The mediation analysis uses 5,000 bootstrap samples, 95\% confidence intervals and linear regressions. 
Table 2. Covariate balance for all three estimations.

\begin{tabular}{|c|c|c|c|c|c|}
\hline & Means treated & $\begin{array}{c}\text { Means } \\
\text { unmatched } \\
\text { not treated }\end{array}$ & $\begin{array}{c}\text { Means matched } \\
\text { not treated }\end{array}$ & $\begin{array}{l}\text { Std. mean diff } \\
\text { before matching }\end{array}$ & $\begin{array}{l}\text { Std. mean diff } \\
\text { after matching }\end{array}$ \\
\hline \multicolumn{6}{|c|}{ (1) All ( $N$ treated $=185, N$ unmatched control $=93, N$ matched control $=185)$} \\
\hline Age & 39.13 & 37.51 & 38.06 & 0.17 & 0.11 \\
\hline Household size & 4.97 & 4.59 & 4.78 & 0.16 & 0.08 \\
\hline $\begin{array}{l}\text { Past } \\
\text { purchasing } \\
\text { behavior }\end{array}$ & 0.31 & 0.17 & 0.24 & 0.34 & 0.16 \\
\hline $\begin{array}{l}\text { Socio- } \\
\text { professional } \\
\text { category }\end{array}$ & 0.29 & 0.40 & 0.32 & 0.25 & 0.08 \\
\hline Education & 0.81 & 0.70 & 0.81 & 0.27 & 0.00 \\
\hline \multicolumn{6}{|c|}{ (2) Ex situ ( $N$ treated $=98, N$ unmatched control $=180, N$ matched control $=98)$} \\
\hline Age & 37.03 & 37.51 & 36.92 & 0.05 & 0.01 \\
\hline Household size & 4.55 & 4.59 & 4.45 & 0.02 & 0.05 \\
\hline $\begin{array}{l}\text { Past } \\
\text { purchasing } \\
\text { behavior }\end{array}$ & 0.30 & 0.17 & 0.30 & 0.30 & 0.00 \\
\hline $\begin{array}{l}\text { Socio- } \\
\text { professional } \\
\text { category }\end{array}$ & 0.41 & 0.40 & 0.41 & 0.01 & 0.00 \\
\hline Education & 0.87 & 0.70 & 0.88 & 0.42 & 0.03 \\
\hline \multicolumn{6}{|c|}{ (3) In situ ( $N$ treated $=62, N$ unmatched control $=216, N$ matched control $=62$ ) } \\
\hline Age & 43.08 & 37.51 & 41.71 & 0.60 & 0.16 \\
\hline Household size & 5.53 & 4.59 & 5.47 & 0.40 & 0.03 \\
\hline $\begin{array}{l}\text { Past } \\
\text { purchasing } \\
\text { behavior }\end{array}$ & 0.39 & 0.17 & 0.39 & 0.50 & 0.00 \\
\hline $\begin{array}{l}\text { Socio- } \\
\text { professional } \\
\text { category }\end{array}$ & 0.21 & 0.40 & 0.26 & 0.43 & 0.11 \\
\hline Education & 0.68 & 0.70 & 0.69 & 0.04 & 0.04 \\
\hline
\end{tabular}

Note: we provide the covariate balance for the three matching specification: all respondents (1), respondents exposed to ex-situ communication means only (2) and respondents exposed to in situ communication means only (3). For each covariate used in the matching procedure, we display means for treated, unmatched non-treated, and matched non-treated respondents as well as the standardized difference in means between treated and control units before and after matching. Bold characters in the Std. Mean Diff. (standardized mean difference) column means the variable is not balanced between the treated and control units (absolute value $>0.25$ standard deviation).

\section{Results}

\section{Pre-Matching Characteristics of Consumers}

Timber consumers interviewed are on average 39 years old and have a family of 5 members on average (Table 2). $61.1 \%$ of them are professional of the wood sector (e.g. sawnwood resellers, carpenters and cabinet makers) and less than $0.3 \%$ of them reported they had bought legal timber before the initiation of the media campaign. Finally, 23\% of respondents have finished high school.

Amongst the 463 respondents, 278 respondents declared they had not heard anything about the legal timber campaign and 185 respondents said they had. Amongst the latter, 62 received information only from in situ sources, 98 only from ex situ sources and 25 from a mix of both.

Comparison of pre-matching covariate distribution (Table 2) suggests that the information campaign reached wood buyers with significant differences in socio-economic characteristics and past behaviors (standard mean difference before matching $>0.25$ ). 
Table 3. Impact estimates.

\begin{tabular}{lcccccc}
\hline & $\begin{array}{c}\text { Means matched } \\
\text { not treated }\end{array}$ & Means treated & Diff in means & Significance & $\begin{array}{c}\text { Std. mean diff } \\
\text { after matching }\end{array}$ & $\Gamma$ \\
\hline All (1) & 4.22 & 5.10 & 0.88 & $* * *$ & 0.52 & 1.7 \\
Ex situ (2) & 4.26 & 5.20 & 0.95 & $* * *$ & 0.56 & 1.7 \\
In situ (3) & 4.26 & 5.15 & 0.89 & $* *$ & 0.54 & 1.6 \\
\hline
\end{tabular}

Note: we provide an estimation of the Average Treatment Effect on the Treated for all respondents (1), respondents only exposed to ex-situ communication channels (2) and respondents only exposed to in-situ communication channels (3). We provide an indicator of the significance of the difference in means between treated and control (***significant at $p<0.001, * *$ significant at $p<0.01$ ). We also estimate Rosenbaum bounds for each matching specification and provide the gamma value, which represents the highest increase in the odds ratio of protection based on the Hodges-Lehmann point estimate for which the DID-matching estimates remain significantly different from zero with a $95 \%$ confidence interval even in the presence of unobserved bias. Finally, we give the number of covariates for which this indicator takes an absolute value above 0.25 as a way to show the quality of covariate balance for each matching.

For example, wood buyers who were exposed to any type of communication channel were significantly more educated and purchased legal wood more often than buyers who were not exposed to information about legal wood. As these characteristics could be associated with higher probability of purchasing legal wood once exposed to the communication campaign, to accurately measure the effectiveness of the programme, we needed to control for observable selection bias.

\section{Impact of the Campaign}

The matching procedure generally improves covariate balance (Table 2). Indeed, none of the normalized difference between control and treated units was greater than 0.25 standard deviations (Table 2). We thus conclude that the covariate balance is acceptable.

The impact of the information campaign was positive and statistically different from zero for all specifications (Table 3). Effect size measured using the standardized means difference is around 0.5. Interestingly, the difference in effect size between in situ and ex situ media channels is not significant.

Finally, the results of Rosenbaum's test (Table 3, last column) show that the impact estimate would not be significantly different from zero if two respondents with the same observable characteristics differed in the odds of being exposed to the media campaign by 1.6 due to unobserved differences.

\section{Mediation analysis: Testing the Pathways between Information and Intention to Purchase}

Figure 2 presents the results of the mediation analysis. Overall, the results confirmed the impact estimates found in Section "Impact of the Campaign". The total effect of information on the intention to purchase legal timber was positive and significant $(\mathrm{C}=0.781 ; p=0.000)$.

The results also showed that the impact of the campaign was mediated by the attitude and the subjective norm. Indeed, information had a significant and positive indirect effect on attitude $(\mathrm{A} 1=0.603 ; p=0.000)$ and on subjective norm $(\mathrm{A} 2=0.343$; 


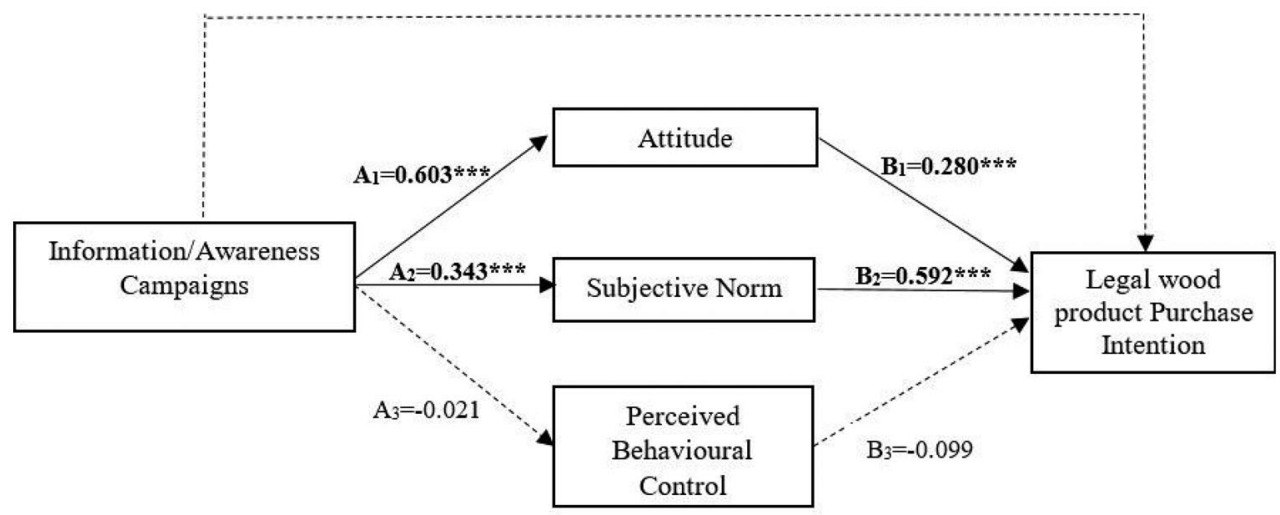

Total effect $\mathrm{C}=0.781^{* * *}$

Figure 2. A statistical path model. Note: Solid lines: Statistically significant result; dotted lines: statistically non-significant result. Note: $* * *$ denote significance at $1 \%$.

$p=0.000)$. What is more, both the attitude $(\mathrm{B} 1=0.280 ; p=0.000)$ and the subjective norm $(\mathrm{B} 2=0.592 ; p=0.000)$ had a positive and significant indirect effect on the intention to purchase.

We also show that PBC did not mediate the effect of information on intentions to purchase legal timber. Indeed, information had no effect on perceived control (A3 = $-0.021 ; \mathrm{P}=0.871$ ) and the effect of perceived control on the intention to purchase legal timber was not significant $(\mathrm{B} 3=-0.099 ; \mathrm{p}=0.081)$.

Finally, we show that among the covariates introduced in the model, past purchasing behavior and education had a positive and significant effect $(p<0.05)$ on attitude while past purchasing behavior had a very positive and significant effect $(p=0.000)$ on the subjective norm (Appendix 2).

\section{Discussion}

Our study contributes to improve the understanding of consumers' purchase intentions for legal timber and wooden furniture in products in Yaoundé, Cameroon. Our study is valid for the sub-population of consumers of wood products purchasing directly from timber markets, joinery workshops and furniture showrooms. Previous value-chain studies suggest that this sub-population's consumption represents an important share of the volume of wood products traded in Yaoundé (Cerutti and Lescuyer 2011; Lescuyer et al. 2017). A census-like sampling would have ensured that our sample is representative of the broader range of consumers of wood products in Yaoundé but would have required a very large sample to capture enough respondents reached by the campaign. Besides, the fact that participation to the survey was voluntary may have led to an underrepresentation of respondents who were aware of the media campaign but who did not change their purchasing intentions. Moreover, our sample presents similar characteristics in terms of socio-professional category, level of education and age of 
consumers to a previous study carried out among a larger sample $(N=440)$ of consumers of sawn timber and wooden furniture in Cameroon (Lescuyer et al. 2017). Our sample is thus likely to be a good representation of the sub-population of sawn wood and wooden furniture consumers buying directly from timber markets, carpentry workshops and furniture showrooms in Yaoundé.

The first part of the study showed that the media campaign had a positive significant effect on consumers' intentions to purchase legal timber in Cameroon. We did not find other study assessing the impact of information, awareness campaigns or nudges on consumption behavior in developing countries. This makes any comparison of the magnitude of the impact difficult. Based on findings from other sectors, we can say that the effect of the media campaign seems to be of medium size (Faraone 2008). Besides, the comparison of the results of the Rosenbaum test with studies evaluating the impact of other types of interventions suggests that our impact estimates are relatively sensitive to the presence of even moderate unobserved bias. The implementation of other impact studies of similar interventions aimed at promoting the consumption of legal wood would help corroborate or contradict the conclusions of our study.

In relation to the previous point, an important hypothesis underlying matching procedures is the absence of omitted variables that are distributed differently between control and treated groups although they could explain the outcome of interest (in our case, purchase intentions) or the selection in the program (in our case, access to information). If it was not the case, selection bias would keep influencing impact estimates. In this study, we are confident that no intervention other than the one studied conveyed information about the legality of wood in Yaoundé. Besides, we controlled for reported purchase behaviors prior to the initiation of the interventions. These two aspects give our results more credibility. However, the fact that we relied on survey data collected after the initiation of the media campaign considerably constrained our options to create a complete set of relevant covariates. Besides, we have limited knowledge of factors facilitating access to media information in this particular type of context. As a result, we probably missed important covariates that could explain the relative sensitivity of our results. For example, the revenue level before the media campaign probably explains differences in the probability to be exposed to the campaign, as it influences the capacity to buy smartphones, computers or televisions. Overall, there is a need to develop more comprehensive models that could guide the selection of covariates and to collect survey data before the initiation of the program.

Our impact evaluation also showed that the impact of the media campaign was significant irrespective of the communication channel. Further, the magnitude of the impact of the awareness campaign did not differ significantly in the three groups (i.e. with access to in-situ/ex-situ, the two information channels). In other words, in our study, the type of media used for the promotion of legal and sustainable timber did not play a decisive role. Besides, it does not seem that combining the two communication channels leaded to higher impact. This result suggests that the value added of combining different communication channels is not the potential "effect of repetition" or the "interaction effect" but rather that it has a wider reach, as almost $90 \%$ of these respondents only had access to one type of information. 
The results of our impact evaluation would have been stronger if we had been able to measure actual consumption behaviors, as purchasing intentions for legal products are not necessarily followed by actual purchasing behaviors (Mainieri et al. 1997; Young et al. 2009). One reason given is that legal products are more expensive than their standard competitors, and this extra cost is not taken into account in the statement of purchasing intentions (Chen and Chang 2012). An additional survey focusing on actual purchasing behaviors would thus be worthwhile, as this was impossible in our case because the survey was done immediately after the campaign.

The second part of the study provides clues concerning the psychological mechanisms that explain the effect of the awareness campaign on the purchasing intentions of legal timber by Cameroonian consumers. We show that two of the three precursors of the theory of planned behavior, namely attitude and subjective norms, were important precursors of the intention to purchase and were also positively influenced by the campaign.

This result is consistent with the results of other studies that demonstrated the explanatory power of the TPB (Johe and Bhullar 2016; Armitage and Conner 2001). However, our study focuses on a different socio-economic context (developing countries versus developed or emerging countries) and on a different type of market (legal versus illegal). Moreover, unlike the conventional use of the TPB, we considered the precursors as mediators of the effect of an intervention, not simply as precursors of behaviors. This is a critical input to determine how communication campaign messages should be framed. In our study, the attitude mediator corresponded to a feeling of responsibility linked to improved knowledge about global environmental problems such as the protection of forests, the fight against climate change and the well-being of future generations. This message was clearly emphasized in the communication campaign. The social norm mediator suggests that the opinion of others, way beyond the family circle, matters to respondents. We postulate that the communication campaign may have sent consumers a signal about societal expectations in terms of consumer behavior with respect to timber products.

Based on our study in Yaoundé, we also argue that the TPB is not sufficient to fully understand the underlying consumption mechanisms or for the design of appropriate communication campaigns. In particular, the TPB fails to provide information about the mechanisms through which an intervention, such as a nudge, influence the three precursors. This black box needs to be opened. Social psychology and behavioral economics document the prescriptive effect of environmental policies, particularly economic incentives, and conceptualizes this effect as the result of an interaction between these external incentives and pro-social motivations or preferences (Bowles and PolaniaReyes 2012; Frey 1992; Rodriguez-Sickert, Guzmán, and Cárdenas 2008). Other authors showed that the perception of the characteristics of a product and the motivations attached to its characteristics are two precursors of attitude (Bennani and Saad 2018). This suggests that improving our understanding of the values, motivations and preferences guiding consumption choices would help understand the connection. Theoretical frameworks such as the self-determination theory (Ryan and Deci 2000) could be useful to conceptualize the origin of the promoters of the TPB by bringing the concept of motivation into play (Hagger and Chatzisarantis 2009; Hagger 2009). 


\section{Conclusion}

Changing the consumers' purchasing behavior could produce significant shifts in the illegal timber trade market. This study conducted in Cameroon shows that the impact of a multi-media campaign in favor of legal timber in Yaoundé positively influenced the respondents' intention to purchase legal timber. This is an encouraging signal for the implementation of the FLEGT Action Plan in producer countries, especially those like Cameroon that are committed to supplying their domestic markets with legal timber. These results also show how national stakeholders could benefit from the implementation of the FLEGT Action Plan that, in southern countries, is often considered as a mechanism aimed primarily at meeting the requirements of European consumers (Carodenuto and Cerutti 2014; Acheampong and Maryudi 2020).

Many steps remain to develop a real domestic demand for legal timber in Cameroon, and more generally in Central African countries. Amongst the many challenges ahead, there is a need both to broaden the panel of consumers sensitive to wood legality and to convert intentions to purchase legal products into acts of purchase. One option would be to repeat this kind of media campaign among all timber buyers in order to trigger a general change in people's perceptions of the importance of acquiring legal wood, which would be equated with quality products, national employment and sustainable forest management. Such general media campaign in favor of sustainable products should be specifically designed to have an overall effect on the subjective norms and attitudes of a significant proportion of national consumers in order to have an effect on the volume of legal timber purchases.

\section{Acknowledgements}

The authors thank Obed Fung and Peter Biggins for their help with the English version of the article. They also acknowledge the contributions of the CIFOR team in Yaoundé, the members of ANCOVA, the University of Yaoundé II, the enumerators and all anonymous respondents interviewed in the timber markets of Yaoundé.

\section{Funding}

This study was supported by the ESSOR project funded by the FAO-EU FLEGT Programme, and by the CGIAR Research Programme on Forests, Trees and Agroforestry.

\section{References}

Abebaw, D., Y. Fentie, and B. Kassa. 2010. The impact of a food security program on household food consumption in Northwestern Ethiopia: A matching estimator approach. Food Policy. 35 (4):286-93. doi:10.1016/j.foodpol.2010.01.002.

Acheampong, E., and A. Maryudi. 2020. Avoiding legality: Timber producers' strategies and motivations under FLEGT in Ghana and Indonesia. Forest Policy and Economics 111:102047. doi:10.1016/j.forpol.2019.102047.

Ajzen, I. 1985. From intentions to actions: A theory of planned behavior. In Action control: from cognition to behavior, eds. Julius Kuhl and Jürgen Beckmann, 11-39. Berlin, Heidelberg: Springer Berlin Heidelberg. 
Ajzen, I. 1987. Attitudes, traits, and actions: dispositional prediction of behavior in personality and social psychology. In Advances in experimental social psychology, eds. Leonard Berkowitz, 1-63. New York: Academic Press.

Ajzen, I., and M. Fishbein. 1980. Understanding attitudes and predicting social behavior. Englewood Cliffs, N.J.: Prentice-Hall.

Armitage, C. J., and M. Conner. 2001. Efficacy of the theory of planned behaviour: A metaanalytic review. The British Journal of Social Psychology 40 (Pt 4):471-99. doi:10.1348/ 014466601164939.

Arriagada, R. A., P. J. Ferraro, E. O. Sills, S. K. Pattanayak, and S. Cordero-Sancho. 2012. Do payments for environmental services affect forest cover? A farm-level evaluation from Costa Rica. Land Economics 88 (2):382-99. doi:10.3368/le.88.2.382.

Bamberg, S., and G. Möser. 2007. Twenty Years after Hines, Hungerford, and Tomera: A New Meta-Analysis of Psycho-Social Determinants of pro-Environmental Behaviour. Journal of Environmental Psychology 27 (1):14-25. doi:10.1016/j.jenvp.2006.12.002.

Baylis, K., J. Honey-Rosés, J. Börner, E. Corbera, D. Ezzine-de-Blas, P. J. Ferraro, R. Lapeyre, U. Martin Persson, A. Pfaff, and S. Wunder. 2016. Mainstreaming impact evaluation in nature conservation. Conservation Letters 9 (1):58-64. doi:10.1111/conl.12180.

Beedell, J., and T. Rehman. 2000. Using Social-Psychology Models to Understand Farmers' Conservation Behaviour. Journal of Rural Studies 16 (1):117-27. doi:10.1016/S07430167(99)00043-1.

Bennani, B., and H. Saad. 2018. La perception et les motivations des consommateurs envers les produits verts [Consumers' perception and motivations for green products]. Public \& Nonprofit Management Review 3:592-9.

Borges, J. A. R., and A. G. J. M. Oude Lansink. 2016. Identifying psychological factors that determine cattle farmers' intention to use improved natural grassland. Journal of Environmental Psychology 45:89-96. doi:10.1016/j.jenvp.2015.12.001.

Börner, J., K. Baylis, E. Corbera, D. Ezzine-de-Blas, J. Honey-Rosés, U. M. Persson, and S. Wunder. 2017. The effectiveness of payments for environmental services. World Development 96:359-74. doi:10.1016/j.worlddev.2017.03.020.

Bowles, S., and S. Polania-Reyes. 2012. Economic incentives and social preferences: Substitutes or complements? Journal of Economic Literature 50 (2):368-425. doi:10.1257/jel.50.2.368.

Brown, D., K. Schreckenberg, N. Bird, P. Cerutti, F. Del Gato, M. Diaw, T. Fomété, C. Luttrell, G. Navarro, R. Hobendorf, et al. 2008. Legal timber. Verification and governance in the forest sector. London: Overseas development Institute.

Carodenuto, S., and P. O. Cerutti. 2014. Forest law enforcement, governance and trade (FLEGT) in Cameroon: Perceived private sector benefits from VPA implementation. Forest Policy and Economics 48:55-62. doi:10.1016/j.forpol.2014.07.010.

Cerutti, P. O., and G. Lescuyer. 2011. The domestic market for small-scale chainsaw milling in Cameroon: Present situation, opportunities and challenges. Bogor, Indonesia: Center for International Forestry Research.

Chan, R. Y. K., and L. B. Y. Lau. 2002. Explaining green purchasing behavior: A cross-cultural study on American and Chinese consumers. Journal of International Consumer Marketing 14 (2-3):9-40. doi:10.1300/J046v14n02_02.

Chen, Y.-S., and C.-H. Chang. 2012. Enhance green purchase intentions. Management Decision 50 (3):502-20. doi:10.1108/00251741211216250.

Coad, L., J. E. Fa, K. Abernethy, N. Van Vliet, C. Santamaria, D. Wilkie, H. R. El Bizri, D. J. Ingram, D.-M. Cawthorn, and R. Nasi. 2017. Toward a sustainable, participatory and inclusive wild meat sector. Montreal, Canada: Center for International Forestry Research. doi:10.17528/ cifor/007046.

D'Hollander, D., and N. Tregurtha. 2016. Exploring the potential of government and voluntary standards collaborations to scale up sustainable production and supply. Policy Matters 21: 60-72.

Faraone, S. V. 2008. Interpreting estimates of treatment effects. P \& T: A Peer-Reviewed Journal for Formulary Management 33 (12):700-11. 
Frey, B. S. 1992. Pricing and regulating affect environmental ethics. Environmental \& Resource Economics 2 (4):399-414. doi:10.1007/BF00304969.

Gan, J., B. Cashore, and M. W. Stone. 2013. Impacts of the Lacey Act Amendment and the voluntary partnership agreements on illegal logging: Implications for global forest governance. Journal of Natural Resources Policy Research 5 (4):209-26. doi:10.1080/19390459.2013.832479.

Gilligan, D. O., and J. Hoddinott. 2007. Is There Persistence in the Impact of Emergency Food Aid? Evidence on Consumption, Food Security, and Assets in Rural Ethiopia. American Journal of Agricultural Economics 89 (2):225-42. doi:10.1111/j.1467-8276.2007.00992.x.

Greenfield, S., and D. Veríssimo. 2019. To what extent is social marketing used in demand reduction campaigns for illegal wildlife products? Insights from elephant ivory and rhino horn. Social Marketing Quarterly 25 (1):40-54. doi:10.1177/1524500418813543.

Greenstone, M., and T. Gayer. 2009. Quasi-experimental and experimental approaches to environmental economics. Journal of Environmental Economics and Management 57 (1):21-44. doi: 10.1016/j.jeem.2008.02.004.

Gurney, G. G., J. E. Cinner, J. Sartin, R. L. Pressey, N. C. Ban, N. A. Marshall, and D. Prabuning. 2016. Participation in devolved commons management: multiscale socioeconomic factors related to individuals' participation in community-based management of marine protected areas in Indonesia. Environmental Science \& Policy 61:212-20. doi:10.1016/j.envsci.2016.04.015.

Hagger, M. S. 2009. Theoretical integration in health psychology: Unifying ideas and complementary explanations. British Journal of Health Psychology 14 (Pt 2):189-94. doi:10.1348/ $135910708 X 397034$.

Hagger, M. S., and N. L. D. Chatzisarantis. 2009. Integrating the theory of planned behaviour and self-determination theory in health behaviour: A meta-analysis . British Journal of Health Psychology 14 (Pt 2):275-302. doi:10.1348/135910708X373959.

Hayes, A. F. 2018. Introduction to mediation, moderation, and conditional process analysis, second edition: A regression-based approach. New York: Guilford Publications.

Ho, D. E., K. Imai, G. King, and E. A. Stuart. 2007. Matching as nonparametric preprocessing for reducing model dependence in parametric causal inference. Political Analysis 15 (3):199-236. doi:10.1093/pan/mp1013.

Ho, D. E., K. Imai, G. King, and E. A. Stuart. 2011. Matchit: Nonparametric preprocessing for parametric causal inference. Journal of Statistical Sofware 42(8). doi:10.18637/jss.v042.i08.

Imbens, G. W., and J. M. Wooldridge. 2009. Recent developments in the econometrics of program evaluation. Journal of Economic Literature 47 (1):5-86. doi:10.1257/jel.47.1.5.

Janmaimool, P., and S. Khajohnmanee. 2020. Enhancing university students' global citizenship, public mindedness, and moral quotient for promoting sense of environmental responsibility and pro-environmental behaviours. Environment, Development and Sustainability 22 (2): 957-70. doi:10.1007/s10668-018-0228-6.

Johe, M. H., and N. Bhullar. 2016. To buy or not to buy: The roles of self-identity, attitudes, perceived behavioral control and norms in organic consumerism. Ecological Economics 128: 99-105. doi:10.1016/j.ecolecon.2016.02.019.

Kleinschmit, D., S. Mansourian, C. Wildburger, and A. Purret. 2016. Illegal logging and related timber trade: Dimensions. Drivers, impacts and responses: A global scientific rapid response assessment report. Vienna: International Union of Forest Research Organizations.

Lalani, B., P. Dorward, G. Holloway, and E. Wauters. 2016. Smallholder farmers' motivations for using conservation agriculture and the roles of yield, labour and soil fertility in decision making. Agricultural Systems 146:80-90. doi:10.1016/j.agsy.2016.04.002.

Lambin, E. F., P. Meyfroidt, X. Rueda, A. Blackman, J. Börner, P. O. Cerutti, T. Dietsch, L. Jungmann, P. Lamarque, J. Lister, et al. 2014. Effectiveness and synergies of policy instruments for land use governance in tropical regions. Global Environmental Change 28:129-40. doi:10. 1016/j.gloenvcha.2014.06.007.

Laroche, M., J. Bergeron, and G. Barbaro-Forleo. 2001. Targeting consumers who are willing to pay more for environmentally friendly products. Journal of Consumer Marketing 18 (6):503-20. doi:10.1108/EUM0000000006155. 
Lescuyer, G., P. O. Cerutti, and R. Tsanga. 2016. Contributions of community and individual small-scale logging to sustainable timber management in Cameroon. International Forestry Review 18 (1):40-51. doi:10.1505/146554816819683744.

Lescuyer, G., R. Tsanga, E. E. Mendoula, B. Xavier Embolo Ahanda, H. A. Ouedraogo, O. Fung, E. Dubiez, and P. B. Logo. 2017. National demand for sawnwood in Cameroon. Bogor, Indonesia: Food and Agriculture Organization, Center for International Forestry Research.

Liobikienè, G., J. Mandravickaite, and J. Bernatonienè. 2016. Theory of planned behavior approach to understand the green purchasing behavior in the EU: A cross-cultural study. Ecological Economics 125:38-46. doi:10.1016/j.ecolecon.2016.02.008.

Mainieri, T., E. G. Barnett, T. R. Valdero, J. B. Unipan, and S. Oskamp. 1997. Green Buying: The Influence of Environmental Concern on Consumer Behavior. The Journal of Social Psychology 137 (2):189-204. doi:10.1080/00224549709595430.

Miteva, D. A., S. K. Pattanayak, and P. J. Ferraro. 2012. Evaluation of biodiversity policy instruments: What works and what doesn't? Oxford Review of Economic Policy 28 (1):69-92. doi:10. 1093/oxrep/grs009.

Nath, V., R. Agrawal, A. Gautam, and V. Sharma. 2017. Antecedents of green purchase intentions: A review and testing of hypothesis on Indian consumers. International Journal of Environment and Sustainable Development 16 (3):297-314. doi:10.1504/IJESD.2017.085071.

Prifti, E., S. Daidone, and B. Davis. 2019. Causal pathways of the productive impacts of cash transfers: Experimental evidence from Lesotho. World Development 115:258-68. doi:10.1016/j. worlddev.2018.11.020.

Rodriguez-Sickert, C., R. A. Guzmán, and J. C. Cárdenas. 2008. Institutions influence preferences: Evidence from a common pool resource experiment. Journal of Economic Behavior \& Organization 67 (1):215-27. doi:10.1016/j.jebo.2007.06.004.

Rubin, D. B. 2001. Using propensity scores to help design observational studies: Application to the tobacco litigation. Health Services and Outcomes Research Methodology 2 (3/4):169-88. doi: 10.1023/A:1020363010465.

Ryan, R. M., and E. L. Deci. 2000. Self-determination theory and the facilitation of intrinsic motivation, social development, and well-being. The American Psychologist 55 (1):68-9. doi:10. 1037/0003-066X.55.1.68..

Salazar, G., M. Mills, and D. Veríssimo. 2019. Qualitative impact evaluation of a social marketing campaign for conservation. Conservation Biology: The Journal of the Society for Conservation Biology 33 (3):634-44. doi:10.1111/cobi.13218.

Samdahl, D. M., and R. Robertson. 1989. Social determinants of environmental concern: specification and test of the model. Environment and Behavior 21 (1):57-81. doi:10.1177/ 0013916589211004.

Shah, P., and K. Baylis. 2015. Evaluating heterogeneous conservation effects of forest protection in Indonesia. PLOS One 10 (6):e0124872-21. doi:10.1371/journal.pone.0124872.

Stuart, E. A. 2010. Matching methods for causal inference: A review and a look forward. Statistical Science: A Review Journal of the Institute of Mathematical Statistics 25 (1):1-21. doi: 10.1214/09-STS313.

Thomas-Walters, L., D. Veríssimo, E. Gadsby, D. Roberts, and R. J. Smith. 2020. Taking a more nuanced look at behavior change for demand reduction in the illegal wildlife trade. Conservation Science and Practice 2 (9):e248. doi:10.1111/csp2.248.

Ulambayar, T., and M. E. Fernández-Giménez. 2019. How community-based rangeland management achieves positive social outcomes in Mongolia: A moderated mediation analysis. Land Use Policy 82:93-104. doi:10.1016/j.landusepol.2018.11.008.

Veríssimo, D., and A. K. Wan. 2019. Characterizing efforts to reduce consumer demand for wildlife products. Conservation Biology: The Journal of the Society for Conservation Biology 33 (3): 623-33. doi:10.1111/cobi.13227.

Wallen, K. E., and E. Daut. 2018. The challenge and opportunity of behaviour change methods and frameworks to reduce demand for illegal wildlife. Nature Conservation 26:55-75. doi:10. 3897/natureconservation.26.22725. 
Webster, F. E. 1975. Determining the characteristics of the socially conscious consumer. The Journal of Consumer Research 2:188-96. doi:10.1086/208631.

Wit, M., J. van Dam, P. Omar, G. Lescuyer, and J. P. Mckeown. 2010. Chainsaw milling: Supplier to local markets - a synthesis. European Tropical Forest Research Network 52:7-22.

Yadav, R., and G. S. Pathak. 2017. Determinants of consumers' green purchase behavior in a developing nation: Applying and extending the theory of planned behavior. Ecological Economics 134:114-22. doi:10.1016/j.ecolecon.2016.12.019.

Young, W., K. Hwang, S. McDonald, and C. J. Oates. 2009. Sustainable consumption: Green consumer behaviour when purchasing products. Sustainable Development 18:20-31. doi:10.1002/ sd.394.

\section{Appendix 1. Likert Scale Validity Test}

To ensure the convergence and reliability of the Likert scales, we used major component factor analysis (MCFA) with a Kaiser-Meyer-Olkin test (KMO), the Cronbach alpha coefficient and the eigenvalue. These tests respectively ensure that the different measurement statements of the same variable are consistent with each other, that they have the ability to provide the same result for several measurements of the same phenomenon, and lastly that they can be used for further analysis (Nath et al., 2017). The table below shows that all the scales were reliable and convergent. The Cronbach alpha coefficients were all greater than 0.7 and the KMO was at least equal to 0.680. The Barlett test remained significant $(\operatorname{sig}=0.000)$ and all built variables with eigenvalues greater than 1 accounted for nearly $60 \%$ of total variance. The three components had at least three items with factor loads between 0.526 and 0.805 , which provided an accurate description of the factor structure required for the study.

\section{Appendix 2. Mediation analysis}

\begin{tabular}{lcrr}
\hline & \multicolumn{3}{c}{ FACTORS } \\
\cline { 2 - 4 } Items & 1 & 2 & 3 \\
\hline Attitudes & & & -0.112 \\
ATT26 & 0.084 & 0.783 & 0.008 \\
ATT34 & 0.186 & 0.771 & 0.070 \\
ATT50 & 0.229 & 2.058 & \\
Eigenvalues & & 0.743 & \\
Cronbach alpha & & 0.682 & \\
KMO & & & 0.042 \\
Subjective Norms & 0.751 & 0.186 & -0.071 \\
SN36 & 0.761 & 0.149 & 0.013 \\
SN38 & 0.614 & -0.004 & 0.046 \\
SN40 & 0.805 & 0.159 & 0.140 \\
SN43 & 0.742 & 0.382 & \\
SN48 & 0.526 & & \\
SN53 & 4.054 & & 0.706 \\
Eigenvalues & 0.821 & & 0.708 \\
Cronbach alpha & 0.860 & -0.076 & 0.638 \\
KMO & & -0.100 & 0.781 \\
Perceived Behavioral Control & 0.003 & 0.079 & 0.500 \\
PBC37 & 0.095 & & 0.674 \\
PBC39 & 0.043 & & \\
PBC45 & -0.020 & & \\
PBC47 & & & \\
Eigenvalues & & & \\
Cronbach alpha & & & \\
KMO & & & \\
\hline
\end{tabular}




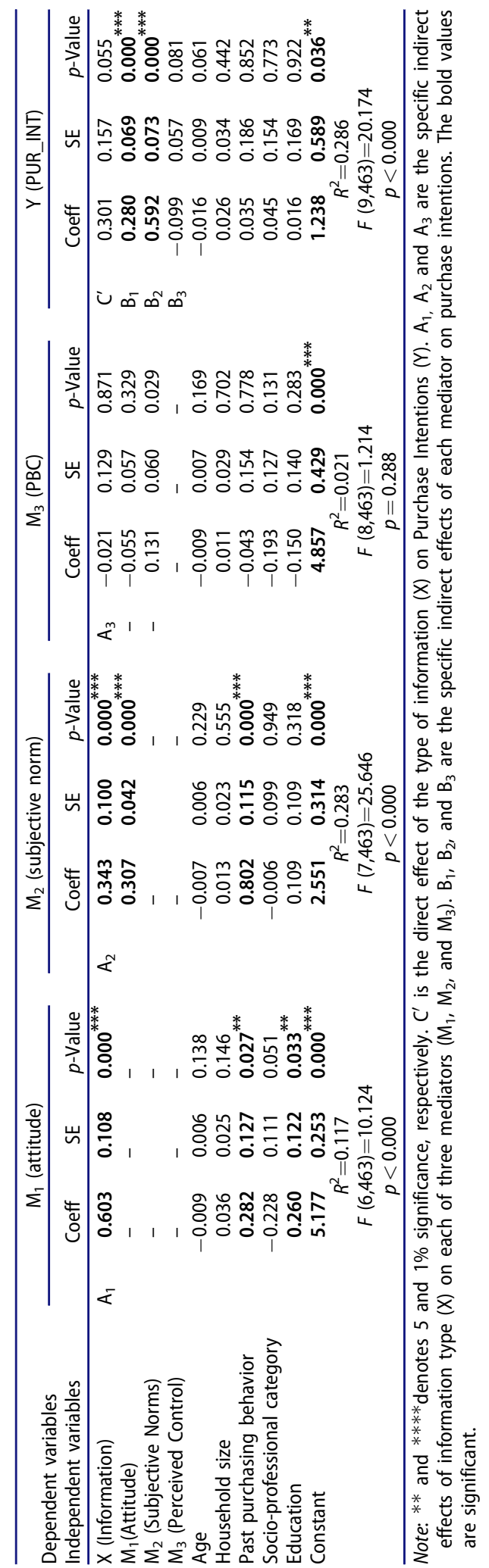

